\title{
Contemporary Bulgarian migration to the countries of the Visegrad Group (V4)
}

\author{
Rossen Koroutchev ${ }^{\mathrm{a}, \star}$ (D), Ladislav Novotný ${ }^{\mathrm{b}}$ \\ ${ }^{a}$ Group of Mediterranean Studies, Universidad Autónoma de Madrid, Madrid, Spain \\ ${ }^{b}$ Institute of Geography, Facutly of Science, Pavol Jozef Šafárik University in Košice, Košice, Slovakia \\ *Corresponding author: rkoroutchev@yahoo.es
}

Key words:

Bulgaria, Migration, Visegrad

countries

\section{ABSTRACT}

The paper studies the contemporary migration of Bulgarians to countries of the Visegrad Group (V4) - the Czech Republic, Slovakia, Hungary and Poland. After making a short historical overview of this phenomenon since the $19^{\text {th }}$ century and the contemporary migration of Bulgarians in the years following 1989, the paper analyses the evolution of Bulgarian migration to the V4 countries in the recent years. The authors conclude that there are important migration flows of Bulgarian citizens towards these countries, due to job perspectives, similar social economic systems and the Bulgarian diaspora already living there.
Article processing

Submitted: 12 April 2021

Accepted: 08 June 2021

Published: 30 June 2021

Academic editor: Georgi Burdarov

(c) R. Koroutchev and L. Novotný. This is an open access article distributed under the terms of the Creative Commons Attribution License (CC BY 4.0), which permits unrestricted use, distribution, and reproduction in any medium, provided the original author and source are credited.

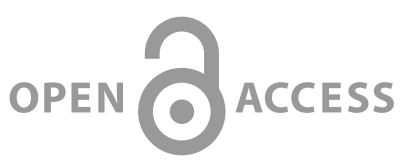

\section{Introduction and theoretical framework}

Migrations between Bulgaria and the territories of the V4 countries have a centuries-old history based on the mutual relationship between them. This phenomenon is still persistent due to the similar historical evolution, traditions and the closeness of the countries. Moreover, after the fall of the Iron Curtain in 1989, the relationship and the migration trends between these countries represent a new era in terms of scientific, economic and cultural exchange, which show the importance of those connections for the development and the common policy of the countries as new members of the EU.

Bulgarians are an ethnic minority in all V4 countries although their number and percentage of the total population vary between countries. The highest percentage of Bulgarians live in the Czech Republic, followed by Hungary, Slovakia and Poland.

In recent history - from the $19^{\text {th }}$ century on - important migration waves from Bulgaria to the V4 countries have been observed, including mainly gardeners and other professionals who migrated to the Austro-Hungarian Empire in large groups in the eighteenth, the nineteenth and the twentieth century, prior to, and after the Balkan War (1912 - 1913), as well as the First World War (1914 - 1918). The Ottoman industry developed rapidly in the first half of the nineteenth century as numerous manufacturing enterprises emerged, demanding urban and rural workforce. Agricultural workers filled the gap left by other workers moving to the cities and the factories there. Thus, the majority of migrants comprised a pool of unskilled industrial and agricultural labourers (Dragostinova and Gerlach 2017).

Another wave of migrants was formed during the period between 1928 and 1929, when Bulgaria, among many other countries, was affected by the world economic crisis. Most of the gardeners came from Northern Bulgaria (Veliko Tarnovo, Ruse, Gabrovo, Lovech and other towns), and settled in the vicinity of Budapest, Szeged and Miskolc in Hungary (Chengova-Menhart 2007), and Bratislava 
and the larger cities of modern-day Slovakia (Rashkova 2005). In the Czech lands, the new settlers were organized into horticultural societies, which had the character of associations whose main purpose was to protect their professional interests (Penchev 2012). Hundreds of young Bulgarians went to Czech secondary schools and universities in Prague, Tábor, Písek and Hradec Králové during the second half of the nineteenth century, in order to return later and fight for the liberation of their homeland (Penchev 2012).

It the nineteenth century the Bulgarian and the Polish nations were under the rule of foreign powers: Bulgaria was ruled by the Ottoman Empire, and Poland was partitioned between Austria, Prussia (later part of Germany) and Russia. Bulgaria regained independence in 1878, and Poland in 1918, which allowed the establishment of diplomatic relations between both countries in 1918, thus enhancing the economic, cultural and demographic exchange between the two countries (Milev 2017).

After the fall of the Iron Curtain in 1989, a migration wave of Bulgarians moving to the Czech Republic was formed, mostly due to economic reasons. The majority of these migrants have been successful, and currently they have stable occupations in the industrial sector, as well as in various services, and especially in the business field, arts and science. After the Bulgarian accession to the EU, many Bulgarians settled in the Czech Republic and Slovakia, working mostly on temporary contracts, thus enriching the Bulgarian diaspora in the two countries. Many Bulgarians who settled in Slovakia succeeded to develop transnational activities in various countries (Penchev 2012). Modern-day migration of Bulgarians to Hungary and Poland is also observed, following Bulgarias accession to the $\mathrm{EU}$ and the period of recovering from the financial crisis of 2008 (KSH 2021, StatPol 2021).

The contemporary migration between Bulgaria and the V4 countries has shown important migration flows towards Bulgaria as well. After the liberation of Bulgaria from the Ottoman occupation in 1878, many Czech and Slovak intellectuals arrived in the country with their knowledge and experience, helping the Bulgarians to learn new engineering and architectural methods. The Czechs and Slovaks who arrived built bridges, railways, railway stations, industrial plants and some important public buildings.

During that turbulent period of reviving of Bulgaria, hundreds of Czechs and Slovaks already lived in Sofia. At that time, they were divided into two groups: one was formed by small entrepreneurs and artisans, and the other - of industrialists. In the 1880s, the Slavonic Beseda association was founded, where Czechs and Slovaks took an active part in the cultural and economic life of Bulgaria (Penchev 2003).

There were also a significant settling of Slovaks in the depopulated areas of Northern Bulgaria in the nineteenth century, who contributed to the raise of the agricultural production, bringing the progressive model of management at that time and the modern agricultural inventory to their new settlements. By the end of World War II, the number of Slovaks in Bulgaria had risen up to 2,000 people, but almost $95 \%$ of them re-emigrated to Czechoslovakia after the war when the Czech-Slovak government called them to return to their homeland in 1945 (Sirácky, 1966, Botík 1994, Bartalská 2001, Hrib 2013).

The contribution of many Hungarians for the development of the Bulgarian lands of the Ottoman Empire was also important. Many of them were attracted by the job opportunities arising from the commercial boom and the construction of the railway network in the region. They were encouraged by the new trends in AustriaHungary's foreign policy towards local market control and cultural influence. That is why Hungarian engineers, doctors, pharmacists, hoteliers, musicians, craftsmen and artists moved to the Bulgarian lands and contributed to the development of the country, among which the most outstanding were the theatre performances and the creation of the first Bulgarian symphony orchestra in Shumen in 1851 (Peykovska 2013).

Finally, it is worth mentioning that the Polish immigrants to Bulgaria of the mid-nineteenth century also had a relevant importance and impact on the Bulgarian national revival. Many Polish immigrants such as talented staff officers, railway and cartographic engineers moved to Bulgaria and had a beneficial effect on both the economic development and the cultural life of the country (Milev 2017).

Based on the above historical and economic ties between Bulgaria and the V4 countries, the paper reviews the modern-day migration of Bulgarians to these countries and how it is evolving in the twentyfirst century. For this purpose we used the theoretical framework previously marked by Markova (2010), Guentcheva (2003) and Siar (2008) in the context of the Bulgarian migration following 1989, the reasons for migration and its consequences. The paper discusses the recent Bulgarian migration to the $\mathrm{V} 4$ countries previously researched by other scholars such as Bogdanova (2019), Penchev (2012), Fruzsina (2017) and Peykovska (2013), in the context of the Czech Republic, Slovakia and Hungary, respectively. In addition, we have used numerous data published by Eurostat and the corresponding Bulgarian and V4 countries' national statistical institutes and state agencies, which also confirm the desire of Bulgarians to emigrate to the $\mathrm{V} 4$ countries - a phenomenon mainly observed after the end of the financial crisis of 2014.

\section{Bulgarians in the V4 countries during the twenty-first century}

\subsection{General characteristics of the contemporary Bulgarian migration}

Since 1989, East European countries have become an important source of immigrants for the Western countries in general and, in particular, the Western European countries. Bulgaria ranked among the countries with the highest emigration levels. On the other hand, following 2013, Bulgaria became an attractive country for immigrants from the Middle East and North Africa (BSAR 2014). However, in most Eastern European countries, as in Bulgaria, emigration rates remain higher that immigration rates. This has been a continuous process for several decades, although its dynamics have changed during the last decades (Markova 2010).

The contemporary migration processes are predetermined by the imbalance of the economic and social developments in Europe and in the World, but also by the various states of the different labor markets. The economic and financial crisis of 2008 and the current COVID-19 pandemic also affected the migration flows, fostering or reducing mobility and aggravating immigrant's security. However, although reduced, the need of immigrant workforce in Europe remains high, while the considerable geographic movements of population require adequate integration policies.

Following 1989, a mass emigration from Bulgaria has affected all classes and categories of the population, ranking the country amongst the top 10 countries generating migrant flows to the EU, after Romania, Poland and Morocco (Markova 2010).

During the period between 1990 and 1994, the employment in Bulgaria dropped by $45 \%$ and the real wages by $52 \%$, the latter affected by two price shocks in 1991 and 1994. In 1996, Bulgaria was facing its most severe political and economic crisis, when inflation hit 300\% and beyond. Physical survival became the most powerful push factor for leaving the country (Siar 2008). 
According to the National Statistical Institute, in 1992 - the year characterized by the highest migration rate, the top 10 municipalities with the highest total number of migrants were: Momchilgrad, Kardzhali region (14,000 emigrants); Dupnitsa, Kyustendil region $(10,000)$; Yambol, Yambol region (8,000); Stamboliiski, Plovdiv region (3,000); Satovcha, Blagoevgrad region (2,800); Sandanski, Blagoevgrad region (2,500); Tutrakan, Silistra region (2,500); Svilengrad, Haskovo region (2,500); Tvarditsa, Sliven region $(2,300)$, and Petrich, Blagoevgrad region (2,000) (Markova 2010). Highly skilled migrants left in search of a more secure life in Western Europe, the USA and Canada. The largest number of migrants moved to Turkey, followed by Spain, Germany, Greece, the USA, Italy, Canada, Austria, the Czech Republic and the Netherlands (Siar 2008).

Spain has become an attractive destination for Bulgarian migrants since 2000 with the expansion of the construction sector. According to the statistics, the total number of registered Bulgarians in Spain as of 1 January 2007 was 118,182 (Markova 2010).

Since 2001, Bulgaria has experienced considerably declining rates of emigration. According to OECD data for the 2001-2004 period, an estimated 60,000 to 100,000 people left the country. According to the State Agency for the Bulgarians Abroad, the Bulgarian emigration was around 820,000 people during the $1985-$ 2010 period (Guentcheva 2003).

The mass emigration, especially from the ethnically mixed regions of Bulgaria, resulted in the depopulation of some border areas in the southeast of the country. At the end of 2004, many border villages in South-Western Bulgaria (mainly in Blagoevgrad region) were depopulated. The depopulation has been considerably intensive also due to the urbanization processes resulting in displacement of population from small and medium-sized urban settlements to big urban centers.

The income per capita in Bulgaria increased by an average of $6 \%$ per year since 1998, and by 2007 the unemployment was only $7 \%$. However, despite the overall positive performance, Bulgaria continues to be the poorest country in the EU.

Following 2008, the global economic and financial crisis caused deterioration of the country's economy resulting in a 3.5\% drop of the GDP and increased unemployment rates, reaching 12\% in 2012 (BIS 2012).

A more recent analysis of the Bulgarian migration shows that the emigration rate is relatively stable and still higher compared to the immigration one: around 30,000 people emigrate every year from Bulgaria, while the country receives around 25,000 immigrants yearly (Fig. 1).

Regarding the immigration to Bulgaria, the first top three countries, whose citizens have obtained Bulgarian citizenship, are shown in Table 1. As it can be seen, the Ukrainian and Russian applicants have been the most numerous since 2013.

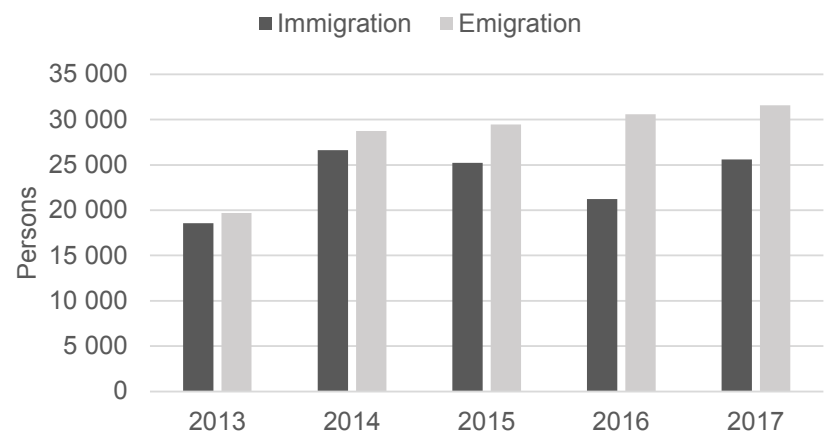

Figure 1. Bulgarian immigration and emigration (2013-2017). Source: Eurostat 2021.
Table 1. Foreign citizens who obtained a Bulgarian citizenship (top 3 countries). Source: NSI 2021.

\begin{tabular}{llll}
\hline Year & \multicolumn{2}{l}{ Countries (number of citizens) } \\
\hline 2017 & Ukraine (204) & Russia (174) & Turkey (110) \\
2016 & Russia (488) & Ukraine (278) & Turkey (145) \\
2015 & Ukraine (224) & Russia (214) & Turkey (179) \\
2014 & Ukraine (202) & Russia (146) & Moldova (126) \\
2013 & Ukraine (134) & Moldova (132) & North Macedonia (127) \\
\hline
\end{tabular}

\subsection{Bulgarians in the Czech Republic}

The Czech Republic is among the top countries in Central and Eastern Europe in terms of economic development. In 2018, its GDP grew by $3 \%$. The industry and the business sector have a positive impact, while the construction and the ICT sector also play an important role.

However, Poland, Hungary and Slovakia are ahead of the Czech Republic in terms of economic growth, mainly due to the workforce shortages in the Czech Republic. This has been acknowledged by the government itself, which introduced changes to the recruitment of foreign workers reaching nowadays $11 \%$ of all workers in the Czech Republic. The majority of them come from Slovakia, Ukraine, Poland, Romania and Bulgaria (CZSO 2021).

Taking into account the fact that foreign citizens make about $5 \%$ of the population of the Czech Republic, their presence on the labour market is more disproportionate. There is an outflow of skilled workers from Eastern Europe to the Czech market (Bogdanova 2019). Bulgarians are a registered ethnic minority in the Czech Republic. The 2011 census recorded 7,435 Bulgarians what constituted $0.07 \%$ of the country's population. As it can be observed in Fig. 2, the number of Bulgarians has continuously increased during the last two decades. Actually, the stable ascending trend of Bulgarian immigrants in the Czech Republic is observed since 2013, when new job opportunities have been created. As a proportion of the Bulgarians emigrating abroad, this represents about 7\% of their total number in 2017.

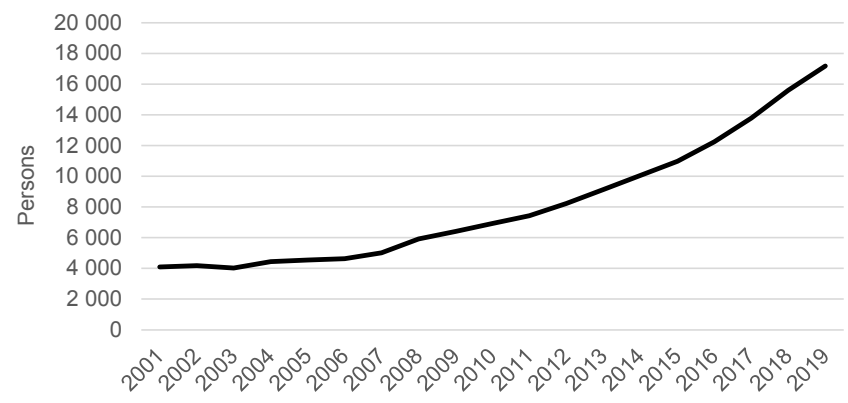

Figure 2. Dynamics of the number of Bulgarian citizens in the Czech Republic, 2001-2019. Source: CZSO 2021a.

Fig. 3 shows the evolution of the number of Bulgarians who have obtained a Czech citizenship. After Bulgaria's accession to the EU, the interest in obtaining a Czech citizenship suddenly dropped. However, after the end of the financial crisis in 2013, the interest grew again. A recent drop has been observed since 2018, mainly due to the slowing down of the Czech economic development.

Bulgarians in the Czech Republic are well integrated, especially those who immigrated long ago and are now well-accommodated. Currently, in the Czech Republic there are 12 active organizations 


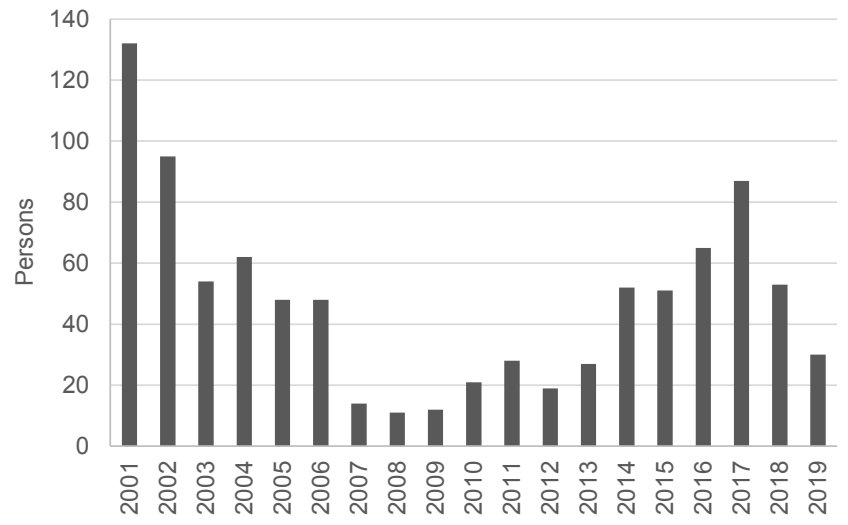

Figure 3. Number of Czech citizenships granted to Bulgarians during the 2001-2019 period. Source: CZSO 2021b.

of Bulgarians - 5 associations, 2 print media, 3 schools and 2 folk groups, located in Prague and Brno.

Interviews conducted during a field trip in 2019 reveal the importance of those immigrants for the country's development:

E. N. (M. 57 years old) I came as a student more than 35 years ago and after graduated from Charles University in Prague and did a PhD in Germany. I applied as a top research manager in the car industry, where I've been working for more than 20 years. I am well-integrated and very happy with my job. The Czech Republic is my second home country.

R. P. (F 54 years old) My family came to The Czech Republic in the 1960s. My father was a Bulgarian gardener, who emigrated for a better life. I was born in The Czech Republic, but I feel both Bulgarian and Czech. On the other hand, I know Bulgarians who came here and went back, as they expected more perspectives for employment.

\subsection{Bulgarians in Slovakia}

Bulgarians in Slovakia are concentrated mainly in the larger towns of Western Slovakia and in the region of Bratislava, although some of them also live in the biggest towns of Central and Eastern Slovakia such as Banská Bystrica, Žilina and Košice, among others. They are represented by several societies such as the Bulgarian Club in Košice, the "Hristo Botev" Civil Association in Bratislava, the Cultural Union of Bulgarians in Banská Bystrica, the "Hristo Botev" Cultural Union of Bulgarians and their friends in Slovakia in Bratislava, the Bulgarian Secondary School "Hristo Botev" in Bratislava (since 1948) (BSO 2020).
Fig. 4 shows the dynamics of the number of Bulgarian nationals in Slovakia. Despite the immigration and the settling of Bulgarian communities in previous centuries in Eastern and Central Slovakia, recently there have been much fewer Bulgarians in these regions. Nonetheless, a significant increase in the number of Bulgarians is seen in all regions. This relatively stable situation persisted until 2006, but a sharp increase occurred from 2007 on, when Bulgaria joined the EU and free movement between both countries was established. The sudden drop seen in 2011 is not due to any actual changes, but rather to statistics corrections based on the population census of 2011. Nevertheless, some consequences of the economic crisis from the late 2000s might have also contributed. After the stabilisation of the economic situation, the number of Bulgarian nationals continued to increase up to more than 2,500 citizens as of 2020 (Datacube 2021). As a proportion of the Bulgarians emigrating abroad, this represents about $5 \%$ of their total number in 2017.

Compared to the Bulgarian community in the Czech Republic, the Bulgarians in Slovakia form a reduced group of mostly elderly people, who emigrated a few decades ago and settled in the country. However, there are also younger, well-integrated Bulgarians in Slovakia.

An interview with a representative of this community, taken during a field trip in 2019, reveals their spirit:

R.D. (F. 40 years old) I live in Bratislava and have dedicated myself to art. I am very happy with my new country of emigration and I feel the people are very friendly and have similar culture and habits. However, I know Bulgarians who have lived here for many years and still don't feel integrated. Maybe it's a question of education and self-esteem.

The Bulgarian community is also much less compared to the Ukrainian community in Slovakia, which holds the top position among the foreign nationals in the country with a valid residence permit as of 2018, when the number of Ukrainians $(24,913)$ was followed by Serbians $(14,208)$, Russians $(4,698)$, Vietnamese $(4,008)$ and Chinese (2,561) (MIAS 2019).

The economic decline in Slovakia in the late 1990s led to a decrease in the number of immigrants from Ukraine, while the total annual numbers of migrants were nearing historical lows during that period. A turning point in this process was the rapid economic growth since 2001, followed by a significant increase in the number of immigrants, which also reflected in the number of the Bulgarian nationals in Slovakia (Fig. 4).

The number of migrants, including those from Bulgaria and Ukraine, started to decrease again in the mid-2000s. However, the

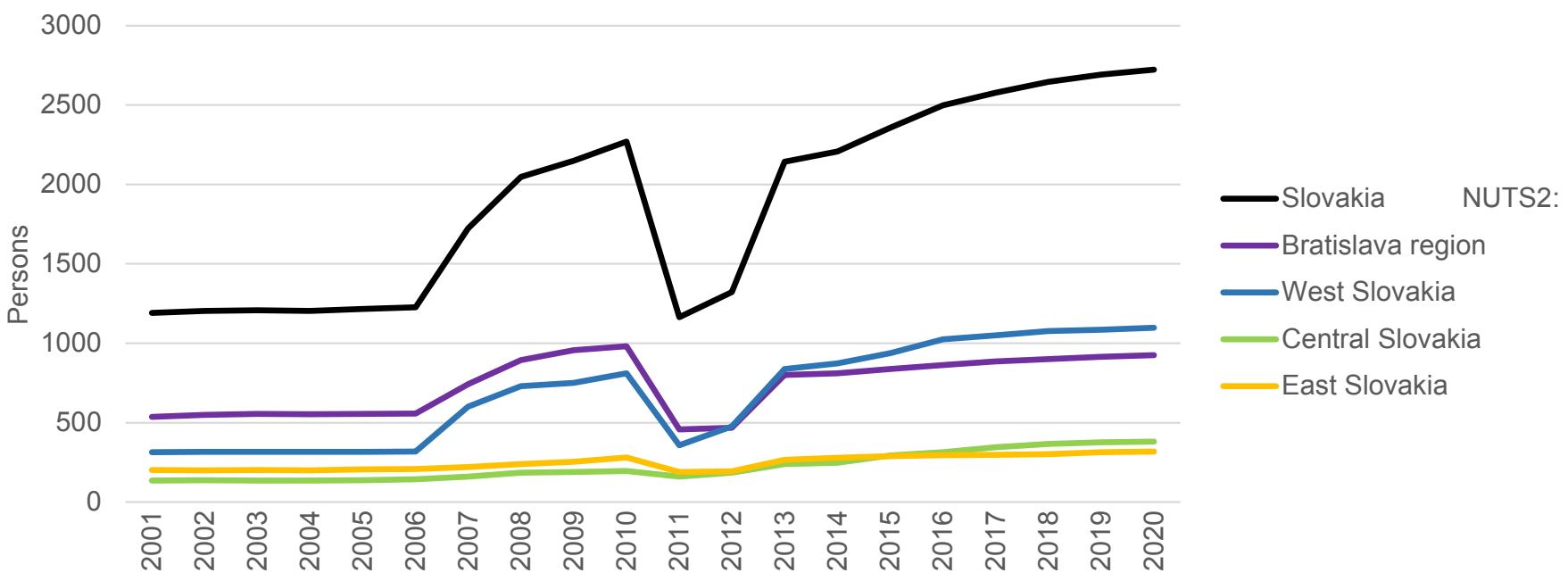

Figure 4. Bulgarian nationals in Slovakia. Source: Datacube 2021. 
growth of the total number of immigrants had not peaked until 2008, when Slovakia was also significantly affected by the global economic crisis. The subsequent decline in the number of immigrants was reversed in 2012. Although the total annual number of immigrants did not reach the 2008's record till the end of the period under consideration, the number of immigrants from Ukraine has been reaching historical highs since the mid-2010s (Koroutchev and Novotný 2020).

Most immigrants to Slovakia go to its western, more economically developed part, with an understandable dominance of Bratislava, which was earlier discussed in the case of Bulgarian immigrants as well. The total number of international migrants to Bratislava exceeded 20,000 and constituted over $17 \%$ of the total international migration to Slovakia during the period between 1996 and 2018. Košice, the second largest city in Slovakia and a major city of Eastern Slovakia, received much less immigrants. However, migration from Ukraine shows substantially different spatial pattern: although Bratislava recorded the largest number of migrants from Ukraine, their number in Košice was only slightly lower, which is in contrast with the pattern of Bulgarian immigrants (see Fig. 4). It should be pointed out that Eastern Slovakia is bordering Polish and Hungarian regions with similar (Malopolskie in Poland) or even lower GDP per capita (Podkarpackie in Poland, and Borsod-Abaúj-Zemplen and Szaboks-Szatmár-Bereg in Hungary). This indicates that Eastern Slovakia could be more attractive for Ukrainians, than Polish or Hungarian regions bordering Ukraine. Actually, Eastern Slovakia has recently recorded a significant increase in the number of Ukrainian immigrants, who are employed in the industry and the services sectors (Koroutchev and Novotný 2020).

\subsection{Bulgarians in Hungary}

The wave of Hungarian emigrants since Hungary's accession to the EU in 2004 has led to labor shortages in the country, particularly in the last decade. Around 500,000 mostly young people, emigrated, in search of better opportunities abroad. Recently, the Hungarian government launched a program to fill vacancies in various sectors such as the IT, telecommunications and the automotive sector. This program has attracted experts from other Eastern European countries, including Bulgaria (Fruzsina 2017).

According to the 2011 census, there were 6,272 Bulgarians in Hungary, constituting $0.06 \%$ of the country's population (KSH 2021).
The intensive cultural activity of the Bulgarian community in Hungary led to the establishment of the Bulgarian newspaper "Bulgarski vesti", the Bulgarian magazine "Hemus", several folk dance groups and orchestras, as well as the Bulgarian native language school, and a Bulgarian-Hungarian Secondary School "Hristo Botev". The Bulgarian Orthodox church of St. Cyril and Methodius in Ferencváros, Budapest, was built in 1932 (Peykovska 2013).

A field trip in 2019 reveals that the Bulgarians in Hungary are well-integrated in the Hungarian society:

M. M. (F. 65 years old) I came to Hungary about 40 years ago after marrying my Hungarian husband. I like Hungary and especially Miskolc, where I started a family and worked in the tourist industry.

R. T. (F. 45 years old) I came to Hungary about 3 years ago, as my husband was promoted in his multinational enterprise. We live in Budapest. I found a job in an NGO and we have good contacts with the local people and with the Bulgarians living in the country, through the association which they created long ago.

\subsection{Bulgarians in Poland}

Compared to the rest of the V4 countries, Bulgarians in Poland are not so numerous. A significant increase of these numbers is observed after 2015, mainly due to the job offers in the industry, agriculture and domestic work (Fig. 5).

A significant increase in the number of Bulgarian immigrants in Poland has been observed since 2015, after a pronounced decrease due to the financial crisis of 2008. This is a manifestation of the positive effects of the recent economic policy of the country.

Bulgarians in Poland feel well-integrated. Although of a small size, the community is very active and regularly organizes events to keep the Bulgarian traditions. They have created the "Friends of Bulgaria" association in Wroclaw, a Bulgarian school on Warsaw - "Dora Gabe", an electronic media, as well as several folklore ensembles (OBP 2016).

An online interview with a Bulgarian living in Poland was conducted in 2021:

D. I. (M. 35 years old) I came to Poland a few years ago to work in the IT sector. I am happy with my job and with the working conditions. I also like very much hiking in the Tatra Mountains. Our community is very traditional and before the COVID-19 pandemic we celebrated many events together. Now this is mostly done online, but it is always a pleasure to meet old friends.

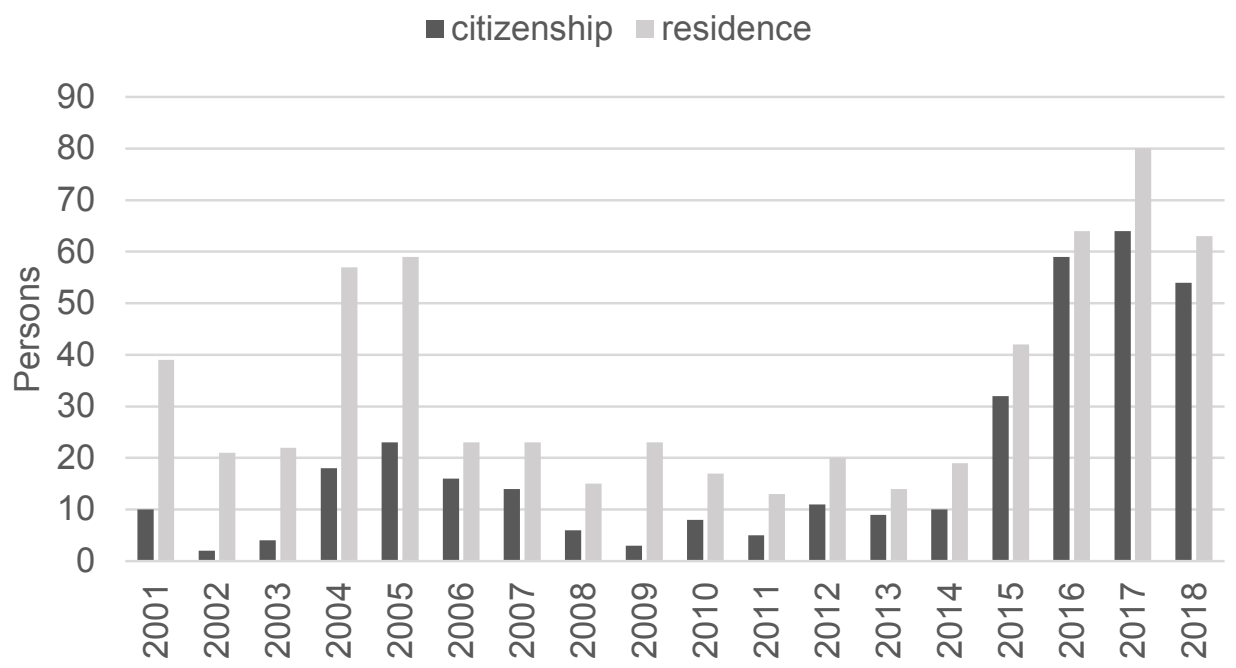

Figure 5. Number of Bulgarians in Poland by citizenship and by country of previous residence. Source: StatPol 2021. 


\section{Conclusions}

The study reveals the recent migration flows between Bulgaria and the countries of the Visegrad 4 Group. Starting from the most important migration phenomena concerning these countries since the nineteenth century, the authors make a short summary of the contemporary Bulgarian migration in general, and finally focus on the rising migration of Bulgarian citizens to the Czech Republic, Slovakia, Hungary and Poland in recent years. Among the pull factors attracting Bulgarian nationals to the V4 countries, the similar traditions, customs and languages, and the proximity of the countries were confirmed as such. The migration interest depends on the economic situation of the host country, the wages and the job perspectives, the Bulgarian diaspora in a given country and the historical ties between home and host countries. The most significant recent Bulgarian immigration flows to the V4 countries are to the Czech Republic and Hungary, showing an increasing and stable rate over the last years, followed by Slovakia and Poland. The emigration to the Czech Republic constituted about $7 \%$ of the total Bulgarian emigration in 2017 and to Slovakia - 5\%. According to the last census (2011), the proportion of Bulgarian migrants to Hungary was about $9 \%$ of the total number of Bulgarian emigrants as of that year.

The Bulgarian migration to Slovakia was compared to that of the Ukrainians and it was shown that the rapid recent economic growth of Slovakia results in a significant increase in the numbers of immigrants to the country. It was pointed out that Eastern Slovakia is bordering Polish and Hungarian regions with similar or even lower GDP per capita, which makes it more attractive for Ukrainian immigrants than Polish or Hungarian regions bordering Ukraine.

The research also confirms the good integration level of the Bulgarians in the V4 countries, where they have established cultural associations, folk dance groups and orchestras, as well as Bulgarian schools. All that contributes to the good integration of the Bulgarian diaspora in the V4 countries, which was also confirmed by the interviews with Bulgarian citizens living there.

\section{Author contributions}

R.K. devised the idea for this study, collected and analysed the data, generated the figures and wrote the original manuscript; L.N. participated in formulating the idea and the main points of the manuscript, assisted in the data analysis, improved some of the figures, the manuscript and the associated literature; All authors have read and agreed to the published version of the manuscript.

\section{References}

Bartalská L’ (2001) Sprievodca slovenským zahraničím. Bratislava: Dom zahraničných Slovákov.

Botík J (1994) Slováci v Bulharsku. Bratislava: Slovenské národné múzeum.

Bogdanova M (2019) Bulgarians and Romanians are heading to the Czech Republic (in Bulgarian), https://fakti.bg/biznes/363002-balgari-irumanci-se-nasochvat-kam-chehia

BSAR (2014) Bulgarian State Agency for Refugees (Printed information offered by the Agency), http://www.aref.government.bg

BSO (2020) Official site of the Bulgarian Secondary School in Bratislava "Hristo Botev", http://bsu-bratislava.com/bg/

Chengova-Menhart P (2007) The firsts. Website of the Bulgarian community in Hungary. Retrieved 2007-02-17.

CZSO (2021a) Czech Statistical Office - Data on number of foreigners https:// www.czso.cz/csu/cizinci/number-of-foreigners-data\#rok

CZSO (2021b) Czech Statistical Office - Data on Bulgarians obtained Czech citizenship, https://www.czso.cz/csu/cizinci/data-on-acqusition-of-czechcitizenship\#cr
Datacube (2021) Demographic Balance of the Bulgarians in Slovakia by County, http://datacube.statistics.sk/\#!/view/en/VBD_DEM/om7002rr/v_ om7002rr_00_00_00_en

Dragostinova Th and Gerlach D (2017) Demography and Population Movements in: The Routledge History Of East Central Europe Since 1700. Routledge: 126-175. https://www.routledgehandbooks.com/ doi/10.4324/9781315230894.ch3

Eurostat (2021) Immigration by age group, sex and citizenship https:// ec.europa.eu/eurostat/en/web/products-datasets/-/MIGR_IMM9CTZ

Fruzsina A (2017) Reforms to the Hungarian public works scheme. ESPN Flash Report 2017/42.

Guentcheva M et al. (2003) Sharing Experience: Migration Trends in Selected Applicant Countries and Lessons Learned from the New Countries of Immigration in the EU and Austria. IOM: 1-106.

Hrib M (2013) Slovenská národnostná menšina na Dolnej zemi. Master Thesis. Pavol Jozef Šafárik University in Košice, Slovakia.

Koroutchev R and Novotný L (2020) Migration in unexploited potential regions: Case study of the Ukrainian migration in Slovakia and its Eastern part. Geographia Cassoviensis, XIV, 144-163. https://uge-share.science. upjs.sk/webshared/GCass_web_files/articles/GC-2020-14-2/02_ Koroutchev_Novotny_144-163_DOI.pdf

KSH (2021) Hungarian population census 2011, national data http://www.ksh. hu/nepszamlalas/tables_regional_00

Markova E (2010) Effects of Migration on Sending Countries: lessons from Bulgaria. GreeSE Paper No 35: 1-49.

MIAS (2019) Statistical Overview of Legal and Illegal Migration in the Slovak Republic. Retrieved from: https://www.minv.sk/swift_data/source/ policia/hranicna_a_cudzinecka_policia/rocenky/rok_2019/2019rocenka-UHCP_EN.pdf

Milev N (2017) Bulgarian-Polish relationships (in Bulgarian) https:// sitebulgarizaedno.com/index.php?option $=$ com_content\&view $=$ articl e\&id=989:im\&catid=29:2010-04-24-09-14-13\&Itemid=61

NSI (2021) National Statistical Institute - Acquisition of citizenship https:// www.nsi.bg/people_on_the_move/bloc-1d.html?lang=en

NSI (2012) National Statistical Institute - GDP, https://www.nsi.bg/en/node/5437

OBP (2016) Organizations of Bulgarians in Poland according to the State Agency for Bulgarians Abroad. Retrieved October 11, 2016. (in Bulgarian) https://www.aba.government.bg/?country $=61$

Penchev Vl (2003) The contribution of the Czechs for the Development of Bulgaria (in Bulgarian). Journal Europa 2001, 5: 14. http://www. euro2001.net/index.shtml?page=statia\&file=issues/5_2003/stat_5. html

Penchev Vl (2012) For Bread... Or for Something Else? (Bulgarian "contracted" labour migrations in former Czechoslovakia in the middle of the last century" in: Migration and Identity Historical, Cultural and Linguistic Dimensions of Mobility in the Balkans, Ed. P. Hristov, Paradigma, Sofia, 2012.

Peykovska P (2013) The Bulgarian community in Hungary at the end of the millennium. Haemus: 5-12, ISSN 1216-2590 (in Bulgarian).

Rashkova N et al. (2005) Bulgarians in Slovakia. Ethno cultural characteristics and interactions, ISBN 954-322-098-0.

Siar Sh (Ed.) (2008) Migration in Bulgaria: A Country Profile. IOM: 1-60.https:// publications.iom.int/es/system/files/pdf/bulgaria_profile2008.pdf

Sirácky J (1966) St’ahovanie Slovákov na Dolnú zem v 18. a 19. storočí. Bratislava: SAV.

StatPol (2021) Statistics Poland, https://stat.gov.pl/en/topics/population/ internationa-migration/demographic-situation-in-poland-up-to2019-international-migration-of-population-in-20002019,6,1.html

\section{ORCID}

https://orcid.org/0000-0003-1105-156X - R. Koroutchev

https://orcid.org/0000-0003-2012-1347 - L. Novotný 